\title{
STUDY OF THE PITUITARY-TESTICULAR AXIS IN HYPOTHYROID ADULT MALE RATS
}

\author{
J. A. VILGHEZ-MARTINEZ* \\ Cátedra de Fisiología, Facultad de Medicina, Universidad del Zulia, \\ Maracaibo, Venezuela
}

(Received 1st January 1973)

Summary. Chronic hypothyroidism induced in adult male rats by ${ }^{131}$ I did not modify the testicular function. This was revealed by the unchanged weight of testes, ventral prostate and seminal vesicles and normal testicular morphology. On the other hand, the anterior pituitary weight was higher in the hypothyroid rats. The pituitary gonadotrophin levels were lower in the ${ }^{131} \mathrm{I}$-treated rats, but this decrease was not apparently sufficient to induce any change in the testicular function.

Existing reports on the influence of the thyroid gland on the male gonads are controversial. Some authors have reported that, in several species, thyroidectomy induced a decrease of gonadal weight (Magssod \& Reineke, 1950) and Karkun \& Mukherjee $(1965,1967)$ reported a decrease in the weight of the seminal vesicles, ventral prostates and epididymides though no histological alterations in the testes were seen. Hammett (1922) and Petersen, Spielman, Pomeroy \& Boyd (1941), however, reported no gonadal alteration after thyroidectomy. In this paper, the influence of the thyroid gland on the male gonads and pituitary gonadotrophin levels has been reinvestigated by inducing hypothyroidism in male rats and studying the repercussions on the gonadal system.

Nineteen, 60-day-old, male rats of the Wistar strain were used. They were allocated to two groups: the rats in one group were injected intraperitoneally with a solution of ${ }^{131} \mathrm{I}$ at a dosage of $1 \mathrm{mCi} / \mathrm{rat}$; those in the other group were treated with a similar volume of normal saline, also injected intraperitoneally. Both groups of rats were kept under similar environmental conditions (14-hr light/10-hr dark cycles), and allowed free access to the standard laboratory diet and water. The animals were killed 180 days later by decapitation, and the anterior pituitaries, testes, ventral prostates and seminal vesicles were removed and quickly weighed. The organ weights of the experimental and control groups were compared and the significance of the differences was investigated by means of Student's $t$ test.

The thyroid glands were removed, fixed in Bouin's solution, processed for routine histological examination and stained with haematoxylin-eosin. The

* Present address: Endocrine and Polypeptide Laboratories, Veterans Administration Hospital and Department of Medicine, Tulane University School of Medicine, New Orleans, Louisiana 70146, U.S.A. 
testes were fixed in Bouin's solution, processed for histological examination and stained with PAS-haematoxylin. The anterior pituitaries were homogenized in saline, quickly frozen and kept at $-20^{\circ} \mathrm{C}$ until assayed for gonadotrophins. Pituitary FSH was determined by means of the method described by Steelman \& Pohley (1953) with slight modifications (Parlow \& Reichert, 1963); 21-dayold female rats of the Sprague-Dawley strain were used.

Pituitary LH was assayed following the method described by Parlow (1961), using 25-day-old female rats of the Wistar strain primed with gonadotrophins as recommended by Sakiz \& Guillemin (1963). The ovarian ascorbic acid concentration was determined by means of the method described by Roe \& Kuether (1943). Relative potencies, precision index, 95\% confidencelimits, and parallelism were investigated using the method of Gaddum (1953).

Table 1. Effects of chronic hypothyroidism induced by ${ }^{131} \mathrm{I}$ on sexual structures of adult male rats

\begin{tabular}{|c|c|c|c|c|c|}
\hline Treatment $\dagger$ & $\begin{array}{l}\text { Final body } \\
\text { weight }(g)\end{array}$ & $\begin{array}{c}\text { Testis } \\
\text { weight }(g)\end{array}$ & $\begin{array}{c}\text { Seminal } \\
\text { vesicle } \\
\text { weight }(m g)\end{array}$ & $\begin{array}{c}\text { Ventral } \\
\text { prostate } \\
\text { weight }(\mathrm{mg})\end{array}$ & $\begin{array}{c}\text { Anterior } \\
\text { pituitary } \\
\text { weight }(\mathrm{mg})\end{array}$ \\
\hline Control (10) & $\begin{array}{r}442.90 \\
\pm 14.23\end{array}$ & $\begin{array}{r}2.892 \\
\pm 0.096\end{array}$ & $\begin{array}{r}626 \cdot 40 \\
\pm 40 \cdot 16\end{array}$ & $\begin{array}{r}590.90 \\
\pm 38.03\end{array}$ & $\begin{array}{c}8 \cdot 72 \\
\pm 0 \cdot 50^{*}\end{array}$ \\
\hline $\begin{array}{l}{ }^{131} \text { I-treated } \\
\text { (9) }\end{array}$ & $\begin{array}{r}405 \cdot 11 \\
\pm 15 \cdot 39\end{array}$ & $\begin{array}{c}3 \cdot 128 \\
\pm 0.061\end{array}$ & $\begin{array}{r}637 \cdot 11 \\
\pm 36.89\end{array}$ & $\begin{array}{r}555.33 \\
\pm 13.90\end{array}$ & $\begin{array}{r}11.96 \\
\pm 0.88\end{array}$ \\
\hline
\end{tabular}

$* P<0.005$.

Values are means \pm S.E.

$\uparrow$ Number of animals in parentheses.

The results obtained in this investigation seem to suggest that hypothyroidism induced in male adult rats by ${ }^{131} \mathrm{I}$ does not affect the testicular function. This conclusion is supported by the fact that no alteration in the weights of the testes, seminal vesicles and ventral prostates was detected in the ${ }^{131}$ I-treated groups compared with the controls (Table 1). Testicular morphology was not altered in the treated rats and the seminiferous tubules as well as the Leydig cells did not show any abnormality. The hypothyroid state of the rats injected with ${ }^{131} \mathrm{I}$ was confirmed since in most of them, the thyroid gland could not be found. In two rats in which thyroid tissue was found, the follicles were few and small, with very little colloid. The present results, which suggest that hypothyroidism does not affect testicular function, are in agreement with the previous ones reported by Hammett (1922) in the rat, and Petersen et al. (1941) in bulls. Moreover, it has been shown that in long-term hypophysectomized rats, a combination of FSH and LH (without thyroid-stimulating hormone supplement) was able to induce a complete recovery of spermatogenesis (Lostroh, 1969). In the present work, the anatomical and physiological states of the organs that constituted the hypophysio-gonadal axis were correlated. The testes and adnexal glands in the hypothyroid animals did not apparently undergo any modification. The lack of alteration in the weights of the adnexal glands in the hypothyroid animals would suggest that no alteration in the function of the Leydig cells actually existed since they are organs under the 
Table 2. Effect of chronic hypothyroidism induced by ${ }^{131} \mathrm{I}$ on pituitary gonadotrophins of adult male rats

\begin{tabular}{|c|c|c|c|c|c|c|}
\hline Treatment* & $L H$ concentration $\dagger$ & $\lambda$ & $\begin{array}{l}\text { LH activity } \\
\text { (ovarian } \\
\text { ascorbic } \\
\text { acid: } \mu g / \\
100 \mathrm{mg}) \S\end{array}$ & $\begin{array}{c}\text { FSH } \\
\text { concentration }+\end{array}$ & $\lambda$ & $\begin{array}{c}F S H \\
\text { activityl } \\
\text { ovarian } \\
\text { weight }(\mathrm{mg} / \\
100 \mathrm{~g}) \mathrm{T}\end{array}$ \\
\hline $\begin{array}{l}\text { Control } \\
(10)\end{array}$ & $\begin{array}{c}6.79 \\
(4 \cdot 24 \text { to } 9 \cdot 90)\end{array}$ & $0 \cdot 170$ & $67 \cdot 41 \pm 2 \cdot 44$ & $\begin{array}{c}35.48 \\
(15 \cdot 42 \text { to } 55 \cdot 86)\end{array}$ & 0.165 & $92 \cdot 23 \pm 3 \cdot 36$ \\
\hline $\begin{array}{l}131 \text { I-treated } \\
(9)\end{array}$ & $\begin{array}{c}4.08 \\
(2 \cdot 29 \text { to } 5 \cdot 88)\end{array}$ & $0 \cdot 176$ & $73 \cdot 67 \pm 1 \cdot 47$ & $\begin{array}{c}28.71 \\
(20.89 \text { to } 36.45)\end{array}$ & 0.135 & $35 \cdot 03 \pm 2 \cdot 72$ \\
\hline
\end{tabular}

* Number of rats in parentheses.

$\dagger$ Method of Parlow (1961). Eight animals per group were used. Expressed as $\mu$ g equiv. NIH-LH$\mathrm{S}_{12} / \mathrm{mg}$ wet weight of anterior pituitary gland with $95 \%$ confidence limits.

$\neq$ Method of Steelman \& Pohley (1953). Eight animals per group were used. Expressed as $\mu$ g equiv. NIH-FSH-S $/$ /mg wet weight of anterior pituitary gland with $95 \%$ confidence limits.

$\$$ Values are means \pm S.E. Each assay rat received $0.1 \mathrm{mg}$ anterior pituitary. Eight animals per group were used. Significance of the difference between control and treated was $P<0.05$.

Tा Values are means \pm S.E. Each assay rat received $1 \mathrm{mg}$ anterior pituitary. Eight animals per group were used. Significance of the difference between control and treated rats was $P<0 \cdot 001$.

direct control of androgens. It would be necessary, however, to determine serum testosterone levels or testicular steroidogenesis in vitro in order to be sure that no alteration in the testosterone secretion could exist. Anterior pituitary weights as well as pituitary gonadotrophin concentrations were lower in the ${ }^{131}$ I-treated group (Table 2). These results, using more specific methods, confirm earlier findings (Contopoulos \& Koneff, 1963; Karkun \& Mukherjee, 1965). It is surprising that although both the concentration and content of $\mathrm{LH}$ in the pituitary were lower in the hypothyroid rats, the weights of the seminal vesicles and ventral prostates, which are known to be androgen-dependent structures, were no different from those observed in the controls. Unfortunately, due to the lack of availability of radioimmunological methods for gonadotrophin measurements, FSH and LH levels in serum could not be studied.

This work was done during the tenure of a fellowship of the 3rd Latin American Course on Biology of Reproduction, at the Centro de Investigaciones sobre Reproducción, Facultad de Medicina, Universidad de Buenos Aires, Argentina.

The author's thanks are due for the constant advice and support of Dr R. E. Mancini, Dr O. Vilar and Dr L. Debeljuk. Thanks are also due to ELEA Laboratories and the National Institute of Health, Bethesda, Maryland for the gift of gonadotrophins used in FSH and LH bioassays, and to Miss A. CastilloGrimaldos for her help in the preparation of the manuscript.

\section{REFERENCES}

Contopoulos, A. N. \& KonefF, A. A. (1963) Pituitary hormone production and release in the thyroidectomized rat after thyroxine administration. Acta endocr., Copenh. 42, 275.

Gaddum, J. H. (1953) Simplified mathematic for bioassays. F. Pharm. Pharmac. 5, 345.

Hammetr, F. S. (1922) Studies on the thyroid apparatus. XI. The effect of thyroparathyroidectomy on reproduction in the albino rat. F. metab. Res. 2, 417. 
KARKUn, J. N. \& MUKheRJEE, A. P. (1965) Some aspects of the changes in the genitalia of hypothyroid male rats. Indian Fnl exp. Biol. 3, 157.

KARKUn, J. N. \& MUKherJeE, A. P. (1967) Effect of prolonged hypothyroidism on reproductive function of male albino rats. Indian Fnl exp. Biol. 5, 9.

Lostron, A. J. (1969) Regulation by FSH and ICSH (LH) of reproductive function in the immature male rat. Endocrinology, 85, 438.

MAGsSoD, M. \& REINEKE, E. P. (1950) Influence of environmental temperatures and thyroid status on sexual development in male mouse. Am. F. Physiol. 162, 24.

ParLow, A. F. (1961) Bioassay of pituitary luteinizing hormone by depletion of ovarian ascorbic acid. In: Human Pituitary Gonadotropins, p. 300. Ed. A. Albert. Charles C. Thomas, Springfield, Illinois.

Parlow, A. F. \& Reichert, L. E. (1963) Species differences in FSH as revealed by the slope in the Steelman Pohley Assay. Endocrinology, 73, 740.

Petersen, W., Spielman, A., Pomeroy, B. S. \& Boyd, W. L. (1941) Effect of thyroidectomy upon sexual behavior of the male bovine. Proc. Soc. exp. Biol. Med. 46, 16.

Roz, J. \& KuETHER, C. A. (1943) The determination of ascorbic acid in whole blood urine through the 2,4-dinitro-phenylhydrazine derivative of dehydroascorbic acid. F. biol. Chem. 147, 399.

Sakiz, E. \& Guillemin, R. (1963) On the method of ovarian ascorbic acid depletion as a test for luteinizing hormone. Endocrinology, 72, 804.

Steelman, S. \& Pohley, F. (1953) Assay of the follicle stimulating hormone based on the augmentation reaction with human chorionic gonadotrophin. Endocrinology, 53, 604. 